\title{
Sedentary lifestyle and poor eating habits in childhood: a cohort study
}

\author{
Sedentarismo e práticas alimentares inadequadas na infância: \\ um estudo de coorte
}

Gisele Ferreira Dutra ${ }^{1}$

Cristina Correa Kaufmann ${ }^{2}$

Alessandra Doumid Borges Pretto ${ }^{1}$

Elaine Pinto Albernaz ${ }^{1}$

${ }^{1}$ Programa de PósGraduação em Saúde e Comportamento, Universidade Católica de Pelotas. R. Gonçalves Chaves 373/411C, Centro. 96015560 Pelotas RS Brasil. gisele_fd@yahoo.com.br ${ }^{2}$ Departamento de Nutrição, Faculdade de Nutrição, Universidade Federal de Pelotas. Pelotas RS Brasil.

\begin{abstract}
Worldwide, about 22 million children under five years old are overweight. Environmental factors are the main trigger for this epidemic. The purpose of this study was to evaluate the eating and physical activity habits in a cohort of eight-year-old children in Pelotas, Brazil. Eating habits were assessed based on the Ten Steps to $\mathrm{He}$ althy Eating proposed by the Ministry of Health. To assess the level of physical activity, the physical activity questionnaire for children and adolescents (PAQ-C) was used. Of the 616 interviewed children at 8 years, it was observed that $50.3 \%$ were male; $70.3 \%$ were white and just over half belonged to economic class $C$. None of the children were classified as very active and none acceded to a daily consumption of six servings of the cereals, tubers, and roots. The steps that had higher adhesion were 8 (do not add salt to ready foods); 4 (consumption of beans, at least 5 times per week) and 1 (have 3 meals and 2 snacks per day), respectively. The high prevalence of physical inactivity and low level of healthy eating habits confirm the importance of strategies to support and encourage the practice of physical activity and healthy eating among youth.
\end{abstract}

Key words Children, Diet, Eating habits, Physical activity
Resumo Mundialmente, cerca de 22 milhões de crianças menores de cinco anos têm excesso de peso, sendo que fatores ambientais são os principais desencadeadores da epidemia. O objetivo deste trabalho foi verificar os hábitos alimentares $e$ de atividade física em crianças de oito anos de idade, pertencentes a uma coorte de Pelotas, Brasil. Os hábitos alimentares foram avaliados com base nos Dez Passos para Alimentação Saudável, propostos pelo Ministério da Saúde. Para avaliar o nivel de atividade física, utilizou-se o questionário de atividade física para crianças e adolescentes (PAQ-C). Das 616 crianças avaliadas aos 8 anos, observou-se que 50,3\% eram do sexo masculino; $70,3 \%$ de cor branca e pouco mais de metade pertencia à classe econômica C. Nenhuma das crianças foi classificada como muito ativa ou aderiu ao consumo diário de 6 porções do grupo de cereais, tubérculos e raízes. Os passos de maior adesão foram o 8 (não adicionar sal aos alimentos prontos); o 4 (consumo de feijão, pelo menos, 5 vezes por semana) e o 1 (realização de 3 refeições e 2 lanches por dia), respectivamente. A alta prevalência de inatividade física e o baixo nivel de hábitos alimentares saudáveis, confirmam a importância de estratégias para apoiar e incentivar a prática de atividade física e alimentação saudável entre os jovens.

Palavras-chave Crianças, Dieta, Hábitos alimentares, Atividade física 


\section{Introduction}

Obesity is a worldwide epidemic and a risk factor in the natural course of several other chronic diseases ${ }^{1}$. With the rise of globalization and its consequences (particularly urbanization, industrialization, and economic development), there are negative changes in the population's lifestyle, including changes in dietary patterns and a decrease in physical activity ${ }^{2}$.

Worldwide, about 22 million children under five years old are overweight and more likely to become obese adults and to suffer from non-communicable chronic diseases $(\mathrm{NCDs})^{3}$. Childhood can be one of the most favorable periods for obesity prevention ${ }^{4}$. However, paradoxically, the management can be more complex than in adult life, since it is related to changes in parents' habits and availability and is inhibited by the lack of knowledge children have on the consequences of this condition ${ }^{5}$.

The etiology of obesity is multifactorial; however, environmental changes comprise the main triggering factors of the epidemic, since they predispose too much consumption of energy associated with lower energy expenditure ${ }^{6}$. Therefore, encouraging the increase of physical activity and the adoption of beneficial dietary habits are the main devices for creating a healthy lifestyle for young people ${ }^{7}$.

Healthy eating should provide water, carbohydrates, proteins, lipids, fiber, vitamins, and minerals, which are essential for preserving health ${ }^{8}$. In terms of physical activity, children and adolescents aged 5-17 years should accumulate at least 60 minutes on a daily basis at a moderate-to-vigorous-intensity level in an activity such as free play, games, sports, transportation, recreation, or planned exercising, in the context of family, school, and community activities ${ }^{9}$. However, national studies indicate unhealthy eating habits such as low consumption of fruits ${ }^{10}$ and vegetables $^{10,11}$, in addition to high consumption of candies and fats ${ }^{10}$ among children. Added to this scenario is the low level of physical activity found in this age group ${ }^{12,13}$.

The aim of this study was to investigate eating and physical activity habits in eight-year-old children, from a cohort in Pelotas, Rio Grande do Sul, Brazil.

\section{Methods}

This is a prospective cohort study of people born between September 2002 and May 2003 in hospitals in the city of Pelotas (RS), Southern Brazil and followed a random sample of $30 \%$ of these, at 30, 90 and 180 days. This study refers to a cross-sectional analysis of data collected in the follow-up that occurred when the children were 8 years of age. These children were visited at home, and trained medical students administered a standardized and pretested questionnaire to mothers or caregivers and children on various aspects of child health, including the frequency, type and intensity of physical activity in the last week and the quantity and quality of the meals in the last month. Details on the cohort methodology are published in Mascarenhas et al. ${ }^{14}$ and Fonseca et al. ${ }^{15}$.

In the present study, the eating and physical activity habits in children aged eight years were evaluated. The assessment of eating habits was based on the Ten Steps to Healthy Eating (Dez Passos para Alimentação Saudável), which were developed by the Brazilian Ministry of Health ${ }^{16}$.

To collect data for each of the steps, we formulated questions that helped confirm the frequency of food consumption within one month before the interview. The response options were divided into seven categories: never, 1-2 times a week, 3-6 times a week, once a day, 2 times a day, 3 times a day, and more than 3 times a day. Step 9 (water) was categorized as it follows with answers: "I: do not take drink water", "do not take drink water every day", statements referring to 1-2 glasses a day, 3-5 glasses a day, 6-8 glasses a day, and more than 8 glasses a day. Steps 1, 8 and 10 were collected by direct questions whose response options were yes or no.

Individuals who reported having at least three meals and two snacks a day were classified as having acceded to step 1. Children who daily consumed six servings from the group of grains, tubers and roots, joined step 2. Daily consumption of at least three servings of vegetables as part of meals and three or more servings of fruit in desserts and snacks, characterized the membership to step 3. Adhesion to step 4 was considered positive when the individual reported the habit of consuming beans at least five times a week. Individuals who daily consumed 3 portions of milk and dairy products, 1 portion of meat, fish, chicken or eggs and removed fat from meat and skin from poultry were classified as having acceded to step 5 . The daily ingestion of no more than 
one serving of vegetable oils, olive oil, butter or margarine constituted the membership to step 6. Likewise, step 7 was considered positive when the child consumed sodas, processed juices, sugar cookies, sandwich cookies, and other treats at most once a day. Step 8 was met when the answer to a question about adding salt to prepared food was "no." Adherence to step 9 occurred when water consumption was at least two liters a day, while step 10 adherence was characterized by at least 30 minutes of physical activity every day and the maintenance of appropriate weight.

To calculate the nutritional status, we analyzed anthropometric data (weight and height) by gender and age during the interview, from which body mass index (BMI) was calculated. The subjects were weighed using a portable scale with a $150 \mathrm{~kg}$ capacity and accuracy to \pm 100 g, wearing light clothing without shoes. Height were measured using a portable stadiometer. Children with score values $\mathrm{z} \geq-2$ and $\leq+1$ were considered to have adequate weight; those with the score $\mathrm{z}<-2$ were underweight; those with BMI with score values $\mathrm{z}>+1$ and $\leq+2$ were overweight, and those with score $\mathrm{z}>+2$ were obese $^{17,18}$.

To assess the level of physical activity, we used the Physical Activity Questionnaire for Children and Adolescents (PAQ-C), developed by Crocker et al. ${ }^{19}$. This survey characterizes the level of physical activity in the seven days preceding its application. It consists of nine questions about the practice of sports, games, and physical activities at school and in free time, including weekends. Each question has a value of one to five, and the final score is obtained by averaging the questions. A score of one is equivalent to a very sedentary lifestyle and five indicates a very active lifestyle. Scores two, three, and four represent the categories sedentary, moderately active, and active, respectively. Participants could be classified as active (score $\geq 3$ ) or sedentary (score $<$ 3). The PAQ -C also includes a question on the average daily time in front of the TV and another on the existence of diseases impeding the normal development of the activities during the previous week, however, these data do not make up the score calculation.

To ascertain the repeatability of the data collected, the field work supervisor repeated a random sample of $10 \%$ of the interviews, using a synthesized questionnaire. The sample size was calculated based on a confidence level of $95 \%$ and a statistical power of $80 \%$, exposures ranging from $15 \%$ to $80 \%$, assuming a Relative Risk (RR) of 2 and increase of $15 \%$ to the initial calculation for losses and confounding factors control. We performed the calculation of the frequencies of the variables, the bivariate analysis between exposure factors and the outcome and between exposure factors and other variables.

The following variables were evaluated: demographic data (gender of the child [male or female], color [white or non-white], and maternal and paternal age in years); socioeconomic data (family income, economic class according to the classification of the Brazilian Association of Research Companies [Associação Brasileira de Empresas de Pesquisa- ABEP ${ }^{20}$, and mother's education); maternal color (white or nonwhite); number of children including the one in the study; marital status (living with a partner or not); maternal smoking; maternal overweight (reported by the interviewee); and characteristics of the child (gestational age, birth weight in grams, duration of breastfeeding, and physical activity). Only the associations with $\mathrm{p}<0.05$ were considered statistically significant.

Epi-Info 6.0 and SPSS (version 21.0) for Windows were used to analyze data. Data were entered twice and checked for consistency. Initially, the frequencies of the variables of interest were obtained to characterize the study sample. Later, bivariate analysis between exposure factors and outcome was done, using chi-squared and linear trend tests.

The research project of perinatal data and visits of one, three, and six months was approved by the Committees of Research and Ethics in Health from Santa Casa de Misericórdia de Pelotas and from Fundação de Apoio Universitário (FAU), and ratified by the Committee of Ethics in Research from Universidade Federal do Rio Grande do Sul and by the Scientific Committee from Universidade Católica de Pelotas. The current research project, with visits to children eight years of age, was approved by the Ethics Committee from Universidade Católica de Pelotas, as this new step was not included in the previous project. Informed consent in writing was obtained from parents or guardians, after they have received detailed and accurate information about the research.

\section{Results and discussion}

In the monitoring conducted at eight years old, it was possible to locate 616 children (63.3\%) of the initial sample of 973 , losses included 5 refus- 
als, 17 deaths, 93 cases of moves to other states or cities, and 242 cases whose addresses could not be found. The sample set of children who were visited was representative of that from the hospital screening.

It was observed that about $10 \%$ of children were born preterm, and $8 \%$ were underweight at birth $(<2500 \mathrm{~g})$. A little more than half of the sample belonged to economic class $\mathrm{C}$, about 70 $\%$ of the children were sedentary and $37.4 \%$ excess weight. The other characteristics are shown in Table 1. More than half of the children were found to be sedentary, and none were found to be very active.

Table 2 shows that frequency of adherence to the Ten Steps to Healthy Eating was low, indicating a possible need to rethink the most effective approach to this population. Vinholes et al. ${ }^{21}$, Raphaelli et al. ${ }^{22}$, and Couto et al..$^{23}$, also exposed low adherence to the steps suggested by the Ministry of Health, in the adult ${ }^{21}$ and adolescent ${ }^{22,23}$ population of the same city. These results are consistent with the prevalence of overweight in this location $^{24}$. In addition, they confirm the findings of Santos et al. ${ }^{25}$, who described the nutritional status of family members in food insecurity in Pelotas/ RS. The authors found high rates of overweight in all age groups, besides height deficit in children aged under five years, implying that food insecurity situation of these families could be related not only to the low availability of food, but also to the poor nutritional value of them.

According to the results, step 1 (having at least three meals and two snacks a day) was mostly adhered by the children $(75.2 \%)$. This was positive, because although there is no consensus about its benefits, the increase on the frequency of meals may reduce appetite, the loss of nitrogen, and improve lipid oxidation and blood markers such as total cholesterol, LDL-cholesterol, and insulin ${ }^{26}$. In a study with dyslipidemic women, Oliveira and Sichieri ${ }^{27}$ suggested that having six daily meals could be a measure of prevention and control of hypercholesterolemia, independent of age, body weight and type of eaten food, fruit, or fiber, once there was a reduction in total and LDL-C serum cholesterol. Furthermore, studies have shown an inverse association between the number of daily meals and $\mathrm{BMI}^{28,29}$.

On the other hand, no children adhered to step 2, which is the daily recommended consumption of six servings of the group of cereals, tubers and roots, preferably whole grains. However, the individual analysis of groups of foods of this step showed that $39.1 \%$ of children had
Table 1. Characteristics of the sample, Pelotas (RS), $2011(\mathrm{~N}=616)$.

\begin{tabular}{|c|c|c|}
\hline Variable & $\mathbf{N}$ & $\%$ \\
\hline \multicolumn{3}{|l|}{ Family income $^{*}$} \\
\hline$\leq 1$ & 85 & 13.8 \\
\hline $1.01-3$ & 308 & 50.0 \\
\hline $3.01-6$ & 144 & 23.4 \\
\hline$>6$ & 66 & 10.7 \\
\hline Unknown & 13 & 2.1 \\
\hline \multicolumn{3}{|l|}{ Economic class $(\mathrm{ABEP})^{\dagger}$} \\
\hline A & 24 & 3.9 \\
\hline B & 202 & 32.8 \\
\hline $\mathrm{C}$ & 325 & 52.8 \\
\hline $\mathrm{D}$ e E & 65 & 10.5 \\
\hline \multicolumn{3}{|l|}{ Maternal Age $e^{\ddagger}$} \\
\hline$\leq 25$ & 52 & 8.4 \\
\hline $26-35$ & 311 & 50.5 \\
\hline$>35$ & 249 & 40.4 \\
\hline Unknown ${ }^{\S}$ & 4 & 0.6 \\
\hline \multicolumn{3}{|l|}{ Maternal Color } \\
\hline White & 456 & 74.0 \\
\hline Not white & 160 & 26.0 \\
\hline \multicolumn{3}{|l|}{ Maternal education } \\
\hline Illiterate /third- grade & 34 & 5.5 \\
\hline Complete fourth-grade & 176 & 28.6 \\
\hline Complete primary school & 133 & 21.6 \\
\hline Complete secundary school & 213 & 34.6 \\
\hline University & 53 & 8.6 \\
\hline Unknown" & 7 & 1.1 \\
\hline \multicolumn{3}{|l|}{ Child gender } \\
\hline Male & 316 & 51.3 \\
\hline Female & 300 & 48.7 \\
\hline \multicolumn{3}{|l|}{ Child color } \\
\hline White & 433 & 70.3 \\
\hline Not White & 183 & 29.7 \\
\hline \multicolumn{3}{|l|}{ Physical activity level } \\
\hline Very Sedentary & 103 & 16.7 \\
\hline Sedentary & 336 & 54.5 \\
\hline Moderately active & 160 & 26.0 \\
\hline Active & 17 & 2.8 \\
\hline \multicolumn{3}{|l|}{ Nutricional Status } \\
\hline Underweight & 11 & 1.8 \\
\hline Normal-weight & 375 & 60.8 \\
\hline Overweight & 126 & 20.5 \\
\hline Obese & 104 & 16.9 \\
\hline
\end{tabular}

${ }^{*}$ In minimum wages; ${ }^{\dagger}$ Classification according to Brazilian Association of Research Companies (Associação Brasileira de Empresas de Pesquisa), emphasizes people's purchasing power without classifying them into social classes. Economic class A comprises people with the highest purchasing power, and economic class E, those with least purchasing power; ${ }^{\ddagger}$ In complete years; ${ }^{\lessgtr}$ Maternal death; ${ }^{\|}$Children who do not live with their mother.

eaten the recommended daily servings of cereals, $6.7 \%$ ate the portions of tubers and roots, and $2.8 \%$ gave priority to whole grains. In the 
Table 2. Frequency of adherence to the items of the 10 Steps to Healthy Eating of the sample, Pelotas (RS), 2011.

\begin{tabular}{|c|c|c|c|}
\hline Steps & Items of the 10 Steps to Healthy Eating & $\mathbf{N}$ & $\%$ \\
\hline Step 1: & Number of meals: at least three meals and two snacks a day & 463 & 75.2 \\
\hline Step 2: & Daily consumption of six portions of cereal, tuber and roots, preferably whole grains & 0 & 0 \\
\hline Step 3: & Daily consumption at least three portions of vegetables and three portions of fruit & 13 & 2.1 \\
\hline Step 4: & Ingestion of beans: at least five times a week & 471 & 76.5 \\
\hline Step 5: & $\begin{array}{l}\text { Daily consumption of } 3 \text { portions of milk and dairy products, } 1 \text { portion of meat, fish, } \\
\text { chicken or eggs and removal of fat from meat and skin from poultry }\end{array}$ & 37 & 6.0 \\
\hline Step 6: & Have one daily portion, at the most, of vegetable oil, olive oil, butter or margarine & 352 & 57.1 \\
\hline Step 7: & $\begin{array}{l}\text { Avoid soda and industrialized juice, cakes, cookies, desserts and sweets. Eat those, at } \\
\text { most, once a day }\end{array}$ & 266 & 43.2 \\
\hline Step 8: & Decrease the amount of salt in food and remove saltshaker from the table & 521 & 84.6 \\
\hline Step 9: & Consumption at least two liters of water a day (six to eight glasses) & 54 & 8.8 \\
\hline Step 10: & Performing regular physical activity and maintaining a healthy weight & 101 & 16.4 \\
\hline
\end{tabular}

studies of Raphaelli et al. ${ }^{22}$ and Couto et al. ${ }^{23}$, the total consumption of such foods was $31.5 \%$ and $21.0 \%$, respectively. To obtain a healthy diet, $55 \%$ to $75 \%$ of the total energetic value of the diet (TEV) must come from total carbohydrates (complexes + free or simple sugars). Of these, $45-65 \%$ of the supplied energy should be derived from foods rich in complex carbohydrates such as grains, tubers, and roots ${ }^{8}$. Whole foods are rich in fiber, vitamins, minerals, and other nutrients ${ }^{30}$, exerting a protective effect against a number of chronic diseases such as diabetes, obesity, and heart disease ${ }^{31}$. Moreover, Esmaillzadeh et al. ${ }^{32}$ showed an inverse association between whole grain consumption and metabolic syndrome, corroborating its benefits to health.

The consumption of vegetables and fruits was also low $(2.11 \%)$. Similar results were found in other studies conducted in Southern Brazil ${ }^{33,34}$, which is worrying because the daily recommendation is for at least three servings of vegetables and three servings of fruits, based on these foods' potential prevention of non-communicable diseases ${ }^{16}$.

Step 4 (consumption of beans at least five times a week) had second-highest adherence (76.5\%), confirming previous studies carried out in this city, which also reported good adherence to this $\operatorname{step}^{22,23}$. Moreover, this result is higher than the one found by Bortolini et al. ${ }^{35}$, who found daily consumption of this legume by $63.4 \%$ of children between 6-59 months of age in Southern Brazil. The percentage found in this study is important, since the Household Budget Surveys $(\mathrm{POF})^{36}$ reveal a decrease in annual per capita household consumption of beans, which is an important source of iron, fiber and, associated with rice, of high quality plant protein ${ }^{8}$.
Confirming previous studies, consumption of beans was associated with non-white skin color ${ }^{37}$, lower socioeconomic status ${ }^{38}$ and lower maternal education $^{39}$ (Table 3).

The fifth step was followed by $6.0 \%$ of children, but by analyzing the items separately, 25\% consumed three servings of milk and dairy products daily. This is higher than the result found by Filha et al. ${ }^{40}$, who reported adequate intake of these foods by about $7 \%$ of the children enrolled in the Public Health System of the city of Aracaju (SE). Regarding the intake of meat, fish, poultry, or eggs, $32.8 \%$ of the sample met the recommendation to consume them once a day. In a research study conducted with adolescents in Pelotas (RS), the frequency of daily consumption of red meat and white meat was $43.0 \%$ and $9.7 \%$, respectively ${ }^{41}$. In the present study, $80.7 \%$ of the respondents reported removing the visible fat from meats. The percentage is higher than the one found in a study with adults, also resident in Pelotas (RS) in which $52.3 \%$ reported the consumption of meat with excess fat ${ }^{42}$.

The sixth step had adhesion of $57.1 \%$ of the sample and as it can be observed in the table 3, being associated with the white race and higher maternal education. Filha et al. ${ }^{40}$ found adequate consumption of fats by only $6.2 \%$ of the children aged between 24 and 35 months, in Aracaju (SE).

Accession to step 7 was associated with the female gender, white race, socioeconomic status and maternal education (Table 3). Vinholes et al. ${ }^{21}$ observed the consumption of foods high in sugar more often than twice a week by $41 \%$ of adults in Pelotas (RS), which were positively associated with age and negatively associated with education. 
Table 3. Frequency of adherence to the 10 Steps to Healthy Eating according to the variables studied. Pelotas (RS), 2011.

\begin{tabular}{|c|c|c|c|c|c|c|c|c|c|c|}
\hline Variable & $\begin{array}{c}\text { Step } \\
1\end{array}$ & $\begin{array}{c}\text { Step } \\
2\end{array}$ & $\begin{array}{c}\text { Step } \\
3\end{array}$ & $\begin{array}{c}\text { Step } \\
4\end{array}$ & $\begin{array}{c}\text { Step } \\
5\end{array}$ & $\begin{array}{c}\text { Step } \\
6\end{array}$ & $\begin{array}{c}\text { Step } \\
7\end{array}$ & $\begin{array}{c}\text { Step } \\
\mathbf{8}\end{array}$ & $\begin{array}{c}\text { Step } \\
9\end{array}$ & $\begin{array}{c}\text { Step } \\
10\end{array}$ \\
\hline Gender $\left[\mathrm{p}\right.$ value $\left.{ }^{*}\right]$ & 0.52 & - & 0.46 & 0.11 & 0.995 & 0.80 & 0.02 & 0.29 & 0.35 & 0.12 \\
\hline Male & 76.3 & - & 2.5 & 79.1 & 6.0 & 56.7 & 38.6 & 86.1 & 9.8 & 18.7 \\
\hline Female & 74.0 & - & 1.7 & 73.7 & 6.0 & 57.7 & 48.0 & 83.0 & 7.7 & 14.0 \\
\hline Skin color $\left[\mathrm{p}\right.$ value $\left.{ }^{*}\right]$ & 0.13 & - & 0.29 & 0.02 & 0.08 & 0.001 & 0.002 & 0.70 & 0.20 & 0.04 \\
\hline White & 76.5 & - & 1.8 & 74.5 & 6.8 & 60.4 & 46.3 & 84.3 & 8.1 & 14.9 \\
\hline Not White & 69.8 & - & 3.4 & 84.9 & 2.5 & 43.7 & 30.3 & 85.7 & 11.8 & 22.7 \\
\hline Economic class $(\mathrm{ABEP}) \alpha\left[\mathrm{p}\right.$ value $\left.{ }^{* *}\right]$ & 0.24 & - & 0.97 & 0.03 & 0.98 & 0.10 & 0.000 & 0.30 & 0.008 & 0.05 \\
\hline A & 75.0 & - & 0.0 & 58.3 & 4.2 & 62.5 & 70.8 & 83.3 & 8.3 & 4.2 \\
\hline B & 76.7 & - & 3.0 & 73.8 & 5.9 & 64.4 & 50.5 & 87.1 & 5.5 & 15.4 \\
\hline $\mathrm{C}$ & 76.0 & - & 1.5 & 78.8 & 6.5 & 51.4 & 37.2 & 83.7 & 8.9 & 16.6 \\
\hline D e E & 66.2 & - & 3.1 & 80.0 & 4.6 & 61.5 & 40.0 & 81.5 & 18.5 & 23.1 \\
\hline Maternal education [ $\mathrm{p}$ value ${ }^{* *}$ ] & 0.22 & - & 0.51 & 0.000 & 0.82 & 0.02 & 0.000 & 0.95 & 0.32 & 0.12 \\
\hline Illiterate /third- grade & 88.2 & - & 5.9 & 82.4 & 2.9 & 50.0 & 20.6 & 85.3 & 11.8 & 26.5 \\
\hline Complete fourth-grade & 72.7 & - & 1.7 & 83.5 & 5.7 & 51.7 & 37.5 & 83.0 & 9.7 & 16.5 \\
\hline Complete primary school & 70.7 & - & 2.3 & 78.2 & 9.0 & 57.9 & 36.1 & 86.5 & 10.5 & 18.8 \\
\hline Complete secundary school & 76.5 & - & 1.9 & 70.9 & 5.2 & 60.6 & 49.3 & 85.5 & 6.6 & 15.0 \\
\hline University & 79.3 & - & 1.9 & 64.2 & 3.8 & 66.0 & 71.7 & 81.1 & 9.4 & 11.3 \\
\hline
\end{tabular}

a Classification according to Brazilian Association of Research Companies (Associação Brasileira de Empresas de Pesquisa), emphasizes people's purchasing power without classifying them into social classes. Economic class A comprises people with the highest purchasing power, and economic class E, those with least purchasing power. ${ }^{*}$ Chi-square test for linear trend. ${ }^{* *}$ Chi-square test for heterogeneity.

Step 8 was the one with largest accession in the sample $(84.6 \%)$, consistent with the result found by Vinholes et al. ${ }^{21}$. This finding is important because excessive sodium ingestion is one of the major modifiable risk factors in the genesis of systemic hypertension $(\mathrm{SH})^{43}$. Furthermore, studies show excessive consumption of foods high in sodium by child ${ }^{44,45}$, so that the $\mathrm{SH}$, which previously reached only the elderly, now also included young people ${ }^{46}$.

The item relating to the consumption of at least two liters of water a day had poor accession $(8.7 \%)$, and was inversely associated with socioeconomic status (Table 3 ). This percentage is lower than the one found in recent studies ${ }^{47,48}$. Furthermore, the association concerning water ingestion and socioeconomic status, differs from other studies $^{47,49}$.

Analyzing step 10, according to Table 3, there was greater adherence by non-white children and those of lower socioeconomic status. We found that about $60 \%$ of the children maintained appropriate weight and $37.4 \%$ were excess weight (Table 1). In a study with children and adolescents from Maceió (AL), the authors observed better results when checking $86.2 \%$ of normal-weight and $13.8 \%$ of excess weight in the sample ${ }^{12}$. However, when assessing the level of physical activity, the prevalence of physical inactivity was $93.5 \%$, whereas in this study was $71.2 \%$. According to Olds et al..$^{50}$, although the rates of childhood overweight and obesity are stabilizing in many countries, they remain high, causing harmful effects on health across the life span. Thus, it becomes necessary to develop interventions that encourage active behaviors such as daily walks, school activities, and programs involving parents and children ${ }^{51}$.

Regarding physical activity, jogging was the most prevalent sport activity both in general population and in the study population (in both genders). Moreover, according to the bivariate analysis, only the gender variable was significantly associated with physical activity, which was found to be more frequent among boys (Table 4). These results confirm previous studies in Pelotas (RS), in which the frequency of physical activity was higher among men ${ }^{21,52,53}$. Corroborating the results found by Hallal et al. ${ }^{54}$, in this study soccer and basketball were the sports played significantly more often among boys, while dancing and volleyball had significantly greater adherence among girls. 
Table 4. Association between physical activity and socio-demographic variables. Pelotas (RS), 2011.

\begin{tabular}{lcc}
\hline \multicolumn{1}{c}{ Variable } & PR $\left(\mathbf{C I}_{95 \%}\right)$ & $\mathbf{p}$ \\
\hline Gender & & 0.03 \\
$\quad$ Male & $1.32(1.03-1.70)$ & \\
$\quad$ Female & 1.00 & \\
Skin color & & 0.51 \\
$\quad$ White & 1.00 & \\
$\quad$ Not white & $1.10(0.84-1.43)$ & \\
Economic class (ABEP) & & 0.51 \\
A & 1.00 & \\
B & $1.87(0.75-4.69)$ & \\
C & $1.66(0.68-4.14)$ & \\
D e E & $1.85(0.70-4.85)$ & \\
Maternal education & & 0.88 \\
Illiterate /third- grade & 1.00 & \\
Complete fourth-grade & $0.88(0.51-1.51)$ & \\
Complete primary school & $0.86(0.49-1.50)$ & \\
Complete secundary school & $0.96(0.57-1.62)$ & \\
University & $0.76(0.38-1.49)$ &
\end{tabular}

"Classification according to Brazilian Association of Research Companies (Associação Brasileira de Empresas de Pesquisa), emphasizes people's purchasing power without classifying them into social classes. Economic class A comprises people with the highest purchasing power, and economic class E, those with least purchasing power. $\mathrm{PR}\left(\mathrm{IC}_{95_{\circ}}\right)$ : Prevalence Ratio and 95\% Confidence Interval.

\section{Conclusions}

Given the increasing rates of childhood obesity and health problems that this condition entails, it is necessary studies to explicate the factors that cause changes in nutritional status in children. Considering this study's findings, it is possible to conclude that adherence to Ministry of Health recommendations was low.

The results confirm the importance of strategies to support and encourage the practice of physical activity and healthy eating among children, which must have intersectional character, comprising health, education and culture policies, and must also integrate the society and family. Only by making children and youth awareness about the importance of healthy habits, the growing obesity epidemic can be reduced, as well as the harms adjacent to this disease, especially the diseases associated with it and, therefore, the burden on health services.

\section{Collaborations}

CC Kaufmann: conception and design of the study, ADB Pretto and GF Dutra: analysis and interpretation of results, drafting and critical revision of intellectual content. EP Albernaz: analysis and interpretation of results and critical review of the content. All authors approved the final version of the manuscript and declare to be responsible for all aspects of the work, ensuring its accuracy and completeness. 


\section{References}

1. World Health Organization (WHO). Obesity: preventing and managing the global epidemic. Report of a WHO Consultation on Obesity. Geneva: WHO; 2000.

2. World Health Organization (WHO). Diet, nutrition and the prevention of chronic diseases. Report of a Joint WHO/FAO Expert Consultation. Geneva: WHO; 2003.

3. World Health Organization (WHO). School policy framework: Implementation of the WHO global strategy on diet, physical activity and health. Geneva: WHO; 2008.

4. Natale R, Scott SH, Messiah SE, Schrack MM, Uhlhorn SB, Delamater A. Design and methods for evaluating an early childhood obesity prevention program in the childcare center setting. BMC Public Health 2013; 13:78.

5. Mello ED, Luft VC, Meyer F. Obesidade infantil: como podemos ser eficazes? J Pediatr 2004; 80(3):173-182.

6. Enes CC, Slater B. Obesidade na adolescência e seus principais fatores determinantes. Rev Bras Epidemiol 2010; 13(1):163-171.

7. Sabia RV, Santos JE, Ribeiro RPP. Efeito Da atividade física associada à orientação alimentar em adolescentes obesos: comparação entre exercício aeróbico e anaeróbico. Rev Bras Med Esporte 2004; 10(5):349-355.

8. Brasil. Ministério da Saúde (MS). Secretaria de Atenção à Saúde, Coordenação- Geral da Política de Alimentação e Nutrição. Guia alimentar para a população brasileira. Brasília: MS; 2005.

9. World Health Organization (WHO). Global recommendations on physical activity for health. Geneva: WHO; 2010.

10. Conceição SIO, Santos CJN, Silva AAM, Silva JS, Oliveira TC. Consumo alimentar de escolares das redes pública e privada de ensino em São Luís, Maranhão. Rev Nutr 2010; 23(6):993-1004.

11. Alves MN, Muniz LC, Vieira MFA. Consumo alimentar entre crianças brasileiras de dois a cinco anos de idade: Pesquisa Nacional de Demografia e Saúde (PNDS), 2006. Cien Saude Colet 2013; 18(11):3369-3377.

12. Rivera IR, Silva MAM, Silva RDTA, Oliveira BAV, Carvalho ACC. Atividade física, horas de assistência à TV e composição corporal em crianças e adolescentes. Arq Bras Cardiol 2010; 95(2):159-165

13. Barros SSH, Lopes AS, Barros MVG. Prevalência de baixo nível de atividade física em crianças pré-escolares. Rev Bras Cineantropom Desempenho Hum 2012; 14(4):390-400.

14. Mascarenhas ML, Albernaz EP, Silva MB, Silveira RB. Prevalence of exclusive breastfeeding and its determiners in the first 3 months of life in the South of Brazil. $J$ Pediatr (Rio J) 2006; 82(4):289-294.

15. Fonseca AL, Albernaz EP, Kaufmann CC, Neves IH, Figueiredo VL. Impact of breastfeeding on the intelligence quotient of eight-year-old children. J Pediatr (Rio J) 2013; 89(4):346-353.

16. Brasil. Ministério da Saúde (MS). Coordenação Geral da Política de Alimentação e Nutrição. Alimentação saudável para todos: siga os 10 passos. Brasil, 2005. [cited 2013 Jun 1]. Available from: http://nutricao.saude.gov. br/documentos/10passos_adultos.pdf
17. Brasil. Ministério da Saúde (MS). Secretária de Atenção à Saúde. Departamento de Atenção Básica. Orientações para a coleta e análise de dados antropométricos de saúde: Norma Técnica do Sistema de Vigilância Alimentar e Nutricional - SISVAN. Brasília: MS; 2011.

18. De Onis M, Onyango AW, Borghi E, Siyam A, Nishida C, Siekmann J. Development of a WHO growth reference for school-aged children and adolescents. Bull World Health Organ 2007; 85(9):660-667.

19. Crocker PR, Bailey DA, Faulkner RA, Kowalski KC, Mcgrath R. Measuring general levels of physical activity: Preliminary evidence for the Physical Activity Questionnaire for Older Children. Med Sci Sports Exerc 1997; 29(10):1344-1349.

20. Associação Brasileira de Empresas de Pesquisa (ABEP). 2008. [cited 2013 Apr 1]. Available from: http://www. abep.org

21. Vinholes DB, Assunção MCF, Neutzling MB. Frequência de hábitos saudáveis de alimentação medidos a partir dos 10 Passos da Alimentação Saudável do Ministério da Saúde: Pelotas, Rio Grande do Sul, Brasil. Cad Saude Publica 2009; 25(4):791-799.

22. Raphaelli CO, Azevedo, MR, Hallal PC. Associação entre comportamentos de risco à saúde de pais e adolescentes em escolares de zona rural de um município do Sul do Brasil. Cad Saude Publica 2011; 27(12):24292440.

23. Couto SF, Madruga SW, Neutzling MB, Silva MC. Frequência de adesão aos "10 Passos para uma Alimentação Saudável” em escolares adolescentes. Cien Saude Colet 2014; 19(5):1589-1599.

24. Gigante DP, Dias-da-Costa JS, Olinto MTA, Menezes AMB, Macedo S. Obesidade da população adulta de Pelotas, Rio Grande do Sul, Brasil e associação com nível socioeconômico. Cad Saude Publica 2006; 22(9):18731879.

25. Santos JV, Gigante DP, Domingues MR. Prevalência de insegurança alimentar em famílias de Pelotas, Rio Grande do Sul, Brasil, e estado nutricional de indivíduos que vivem nessa condição. Cad Saude Publica 2010; 26(1):41-49.

26. La Bounty PM, Campbell BI, Wilson J, Galvan E, Berardi J, Kleiner SM, Kreider RB, Stout JR, Ziegenfuss T, Spano M, Smith A, Antonio J. International Society of Sports Nutrition position stand: meal frequency. J Int Soc Sports Nutr 2011; 8:4.

27. Oliveira MC, Sichieri R. Fracionamento das refeições e colesterol sérico em mulheres com dieta adicionada de frutas ou fibras. Rev Nutr 2004; 17(4):449-459.

28. Holmback I, Ericson U, Gullberg B, Wirfalt E. A high eating frequency is associated with an overall healthy lifestyle in middle-aged men and women and reduced likelihood of general and central obesity in men. $\mathrm{Br} \mathrm{J}$ Nutr 2010; 104(7):1065-1073.

29. Bachman JL, Phelan S, Wing RR, Raynor HA. Eating frequency is higher in weight loss maintainers and normal-weight individuals than in overweight individuals. J Am Diet Assoc 2011; 111(11):1730-1734. 
30. Slavin J. Why whole grains are protective: biological mechanisms. Proc Nutr Soc 2003; 62(1):129-134.

31. Ye EQ, Shacko SA, Chou EL, Kuqizaki M, Liu S. Greater whole-grain intake is associated with lower risk of type 2 diabetes, cardiovascular disease, and weight gain. Nutr 2012; 142(7):1304-1313.

32. Esmaillzadeh A, Mirmiran P, Azizi F. Whole-grain consumption and the metabolic syndrome: A favorable association in Tehranian adults. Eur J Clin Nutr 2005 59(3):353-362.

33. Costa LCF, Vasconcelos FAG, Corso ACT. Fatores associados ao consumo adequado de frutas e hortaliças em escolares de Santa Catarina, Brasil. Cad Saude Publica 2012; 28(6):1133-1142.

34. Muniz LC, Zanini RV, Schneider BC, Tassitano RM, Feitosa WMN, González-Chica DA. Prevalência e fatores associados ao consumo de frutas, legumes e verduras entre adolescentes de escolas públicas de Caruaru, PE. Cien Saude Colet 2013; 18:393-404.

35. Bortolini GA, Gubert MB, Santos LMP. Consumo alimentar entre crianças brasileiras com idade de 6 a 59 meses. Cad Saude Publica 2012; 28: 1759-1771.

36. Instituto Brasileiro de Geografia e Estatística (IBGE). Pesquisa de orçamentos familiares 2008-2009: análise do consumo alimentar pessoal no Brasil. Rio de Janeiro: IBGE; 2011.

37. Sichieri R, Castro JFG, Moura AS. Fatores associados ao padrão de consumo alimentar da população brasileira urbana. Cad Saude Publica 2003; 19(Supl. 1):S47-S53.

38. Velásquez-Meléndez G, Mendes LL, Pessoa MC, Sardinha LMV, Yokota RTC, Bernal RTI, Malta DC. Tendências da frequência do consumo de feijão por meio de inquérito telefônico nas capitais brasileiras, 2006 a 2009. Cien Saude Colet 2012; 17(12):3363-3370.

39. Dos Santos Barroso G, Sichieri R, Salles-Costa R. Relationship of socio-economic factors and parental eating habits with children's food intake in a population-based study in a metropolitan area of Brazil. Public Health Nutr 2012; 17(1):156-161.

40. Filha EOS, Araújo JS, Barbosa JS, Gaujac DP, Santos CFS, Silva DG. Consumo dos grupos alimentares em crianças usuárias da rede pública de saúde do município de Aracaju, Sergipe. Rev Paul Pediatr 2012; 30(4):529-536.

41. Assunção MCF, Dumith SC, Menezes AMB, Araújo CL Schneider BC, Vianna CA, Machado EC, Wehrmeister FC, Muniz LC, Zanini RV, Orlandi SP, Madruga SW. Consumo de carnes por adolescentes do Sul do Brasil. Rev Nutr Campinas 2012; 25(4):463-472.

42. Schneider BC, Silva SM, Assunção MCF. Consumo de Carnes por Adultos do Sul do Brasil: Um Estudo de Base Populacional. Cien Saude Colet 2014; 19(8):35833592.

43. Sociedade Brasileira de Cardiologia, Sociedade Brasileira de Hipertensão, Sociedade Brasileira de Nefrologia. VI Diretrizes Brasileiras de Hipertensão. Arq Bras Cardiol 2010; 95(1 Supl.1):1-51.
44. Costa FP, Machado SH. O consumo de sal e alimentos ricos em sódio pode influenciar na pressão arterial das crianças? Cien Saude Colet 2010; 15(Supl. 1):13831389.

45. Matuk TT, Stancari PCS, Bueno MB, Zaccarelli, EM Composição de lancheiras de alunos de escolas particulares de São Paulo. Rev Paul Pediatr 2011; 29(2):157163.

46. Ferreira JS, Aydos RD. Prevalência de hipertensão arterial em crianças e adolescentes obesos. Cien Saude Colet 2010; 15(1):97-104.

47. Goodman AB, Blanck HM, Sherry B, Park S, Nebeling L, Yaroch AL. Behaviors and Attitudes Associated With Low Drinking Water Intake Among US Adults, Food Attitudes and Behaviors Survey, 2007. Prev Chronic Dis 2013; 10:E51.

48. Feferbaum R, Abreu LC, Leone C. Fluid intake patterns: an epidemiological study among children and adolescents in Brazil. BMC Public Health 2012; 12:1005.

49. Kant AK, Graubard BI, Atchison EA. Intakes of plain water, moisture in foods and beverages, and total water in the adult US population - nutritional, meal pattern, and body weight correlates: National Health and Nutrition Examination Surveys 1999-2006. Am J Clin Nutr 2009; 90:655-663.

50. Olds T, Maher C, Zumin S, Péneau S, Lioret S, Castetbon K, Bellisle, de Wilde J, Hohepa M, Maddison R, Lissner L, Sjöberg A, Zimmermann M, Aeberli I, Ogden C, Flegal K, Summerbell C. Evidence that the prevalence of childhood overweight is plateauing: data from nine countries. Int J Pediatr Obes 2011; 6(5-6):342-360.

51. Shultz SP, Browning RC, Schutz Y, Maffeis C, Hills AP Childhood obesity and walking: guidelines and challenges. Int J Pediatr Obes 2011; 6(5-6):332-341.

52. Hallal PC, Matsudo SM, Matsudo VKR, Araújo TL, Andrade DR, Bertoldi AD. Physical activity in adults from two Brazilian areas: similarities and differences. Cad Saude Publica 2005; 21(2):573-580.

53. Azevedo MR, Araujo CL, Reichert FF, Siqueira FV, Silva MC, Hallal PC. Gender differences in leisure time physical activity. Int J Public Health 2007; 52(1):8-15.

54 Hallal PC, Bertoldi AD, Gonçalves H, Victora CG. Prevalência de sedentarismo e fatores associados em adolescentes de 10-12 anos de idade. Cad Saude Publica 2006; 22(6):1277-1287.

Artigo apresentado em 05/10/2014

Aprovado em 22/08/2015

Versão final apresentada em 24/08/2015 
